\title{
EFFECT OF PROCAINE AND TETRAETHYLAMMONIUM ON ADRENAL MEDULLARY FUNCTION
}

\author{
TERUO NAKAMURA* \\ Department of Physiology, Nagasaki University School of Medicine, Nagasaki
}

The paralytic effect of procaine and tetraethylammonium ion on the adrenal medullary function has been reported by many investigators.

In atropinized dogs, Hazard and Corteggiani (1) were able to annul by the administration of procaine nearly or wholly the blood pressure elevation causable by asphyxiation. As a similar result was obtained by the removal of suprarenal glands of both sides, they concluded that procaine suppressed the augmentation of adrenaline secretion elicitable by asphyxiation. Bergmann (2) demonstrated that the rise of blood pressure of the dog caused by electrical stimulation of the splanchnic nerves was markedly reduced by intravenous injection of procaine. Further, in estimating the adrenaline content of adrenal venous blood specimens with the rabbit intestinal segment method, he presented an evidence that the acceleration of adrenaline secretion due to insulin hypoglycemia was totally suppressed by procaine. However, precise value of adrenaline secretion rate was not given in his paper.

Morrison (3) observed in dogs that the morphine hyperglycemia, which was assumed by him to be due to an augmented adrenaline secretion from the adrenal glands was markedly diminished by tetraethylammonium. In cats whose superior cervical ganglion was removed four days prior to the experiment, Morrison and Farrar (4) showed that the contraction of the denervated nictitating membrane produced by electrical stimulation of splanchnic nerves was suppressed by the intravenous injection of tetraethylammonium. Evidence was given by Morrison, Heymans, Richardson and Walker (5) that in atropinized dogs the rise of blood pressure elicitable by acetylcholine injection, which was considered by them to be largely due to adrenaline or noradrenaline secreted from the suprarenals, was reduced by tetraethylammonium. Using. the method of suprareno-jugular anastomosis in dogs, Malméjac, Chardon and Neverre (6) presented evidence that tetraethylammonium lessened the rate of adrenaline secretion in acting on the adrenal medulla and the endings of the adrenalino-secretory nerve fibres. Jourdan and Duchêne-Marullaz (7) observed in dogs an inhibitory effect of tetraethylammonium on the adrenaline secretion due to splanchnic stimulation, the volume of the denervated kidney or the rate of the denervated heart being taken as an index of adrenal activity.

As above stated, the paralytic effect of procaine and tetraethylammonium seems to have been confirmed, but mostly by indirect examinations. In the

Received for publication August 7, 1954.

* 中村照夫 
present investigation, attempts were made to study quantitatively how these two chemicals interfere with the acceleration of adrenaline secretion elicitable by acetylcholine.

\section{METHOD}

Dogs, 9-17 kg. in weight, were used. The animals were anesthetized with evipan-sodium given intravenously and maintained by its intravenous supplements as required.

For collecting the adrenal venous blood, the lumbar route preparation of Satake et al. (8) was applied. The blood was rendered incoagulable by heparin sodium. The adrenaline contents of the adrenal venous blood specimens were estimated by the arseno-molybdic acid method of Bloor and Bullen (9). Adrenaline base (Sankyo) was used as the reference standard. In most experiments the blood pressure was recorded by the mercury manometer connected with the femoral artery.

After atropinizing the animal, acetylcholine (Hoffmann La Roche) was injected intravenously in a dose of 2-3 mg. per kg. in 10-20 seconds. After a while procaine (J. P.) in a dose of $50-70 \mathrm{mg}$. per $\mathrm{kg}$. or tetraethylammonium chloride (Etamon chloride, Parke Davis) in a dose of 10-20 mg. per $\mathrm{kg}$. was injected intravenously. Then acetylcholine in the same dose as before was again injected. Thus the adrenaline secretion rates after the first and the second acetylcholine injection were estimated and compared with each other.

\section{RESULTS}

In two dogs control experiments were performed, using neither procaine nor tetraethylammonium. In Dog 1, after the application of atropine, $2 \mathrm{mg}$. each of acetylcholine per $\mathrm{kg}$. were twice injected intravenously at an interval of 20 minutes. Soon after the first injection, the blood pressure began to rise from $112 \mathrm{~mm} \mathrm{Hg}$ and reached $194 \mathrm{mmHg}$. By the second injection, the blood pressure was elevated from $102 \mathrm{~mm} \mathrm{Hg}$ to $222 \mathrm{~mm} \mathrm{Hg}$. The initial rate of adrenaline secretion in this dog was $0.06 \mu \mathrm{g}$. per $\mathrm{kg}$. of body weight per minute. On receiving acetylcholine it increased remarkably. It was estimated that the value during the first sixty-second-period was $1.2 \mu \mathrm{g}$. per $\mathrm{kg}$. per minute. The rate of adrenaline secretion after the second acetylcholine injection was estimated to be $1.4 \mu \mathrm{g}$. per $\mathrm{kg}$. per minute. Thus no noticeable difference was found between the values after the first and the second acetylcholine injection.

A similar result was obtained in Dog 2. Before acetylcholine injection, the rate of adrenaline secretion was too small to be estimated. After the first acetylcholine injection it increased to $3.1 \mu \mathrm{g}$. per $\mathrm{kg}$. per minute. The value after the second acetylcholine injection was just the same with that after the first.

\section{Procaine}

After atropine application, acetylcholine was injected intravenously in a dose of $2-3 \mathrm{mg}$. per $\mathrm{kg}$. of body weight. Soon after the injection the blood 
pressure began to rise. After reaching its maximum the blood pressure fell slowly, or in some cases abruptly. Then it rose again step by step and afterwards it descended gradually. Eleven to 25 minutes after the first acetylcholine injection procaine in a dose of 50-70 mg. per $\mathrm{kg}$. of body weight was injected. On receiving procaine the blood pressure began to fall and the low level lasted for a while. After procaine the injection of acetylcholine was performed again. In a striking contrast with the elevation of blood pressure after the first acetylcholine injection, a profound fall was observed. However, soon it began to rise and resumed the initial level within one minute or so.

As an example the blood pressure tracings of Dog 5 are reproduced in fig. 1. In this dog the blood pressure before the first acetylcholine injection was $114 \mathrm{~mm} \mathrm{Hg}$. Following the injection it began to rise and reached $210 \mathrm{~mm} \mathrm{Hg}$ within 30 seconds after the start of injection. Then it fell to $94 \mathrm{~mm} \mathrm{Hg}$ with a steep descent. Afterwards the blood pressure rose again step by step and $148 \mathrm{~mm} \mathrm{Hg}$ was reached within about 2.5 minutes after the start of injection. Then it descended very slowly. Two minutes later it was $130 \mathrm{~mm} \mathrm{Hg}$. After procaine injection, the blood pressure was $92 \mathrm{mmHg}$ before the second acetylcholine injection. By receiving acetylcholine, it began to fall and $30 \mathrm{~mm} \mathrm{Hg}$ was reached within 30 seconds after the start of injection. Then it ascended gradually and about 90 seconds later it reached $84 \mathrm{mmHg}$.
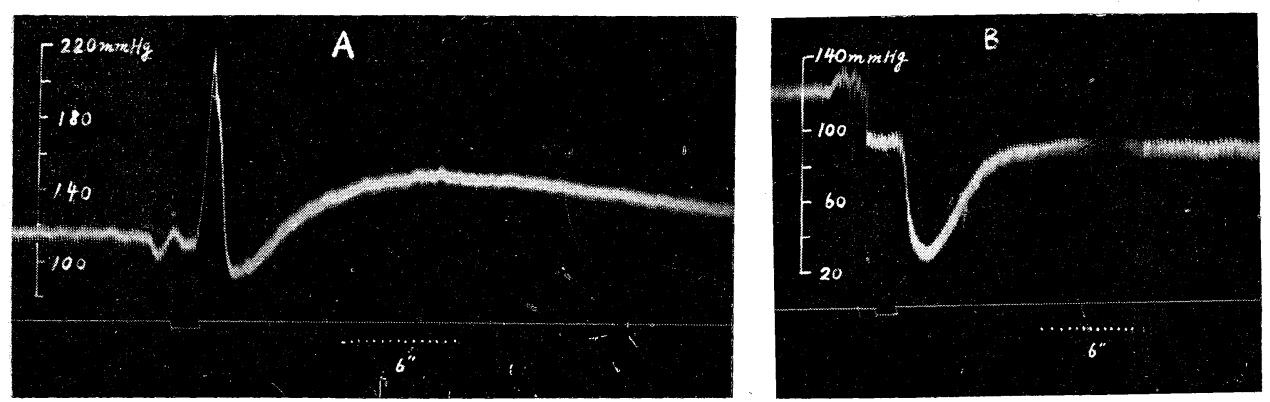

FIG. 1. Blood pressure tracings of Dog 5 (11.8 kg. $\hat{o}$, evipan-sodium anesthesia). $(A)$ : before procaine. $(B)$ : after procaine.

At signal injected acetylcholine in a dose of $2 \mathrm{mg}$. per $\mathrm{kg}$.

In Dog 3 the adrenaline secretion rate before the first acetylcholine injection was $0.02 \mu \mathrm{g}$. per $\mathrm{kg}$. per minute. On receiving acetylcholine, it was accelerated remarkably. The value during the first two-minute-period was estimated to be $0.34 \mu \mathrm{g}$. per $\mathrm{kg}$. per minute. After the second acetylcholine injection the rate of adrenaline secretion was estimated to be $0.04 \mu \mathrm{g}$. per $\mathrm{kg}$. per minute.

In Dog 4 the initial rate of adrenaline secretion could not be estimated as the adrenaline content of the suprarenal venous blood was unmeasurably small. With the specimen sampled during the first thirty-second-period after the first acetylcholine injection, it was found to increase to $1.57 \mu \mathrm{g}$. per $\mathrm{kg}$. per minute. In the next thirty-second-period it was estimated to be $0.01 \mu \mathrm{g}$. From these estimates the value during the first sixty-second-period was calculated as 0.79 
$\mu \mathrm{g}$. per $\mathrm{kg}$. per minute. The rate of adrenaline secretion before the second acetylcholine injection was $0.03 \mu \mathrm{g}$. per $\mathrm{kg}$. per minute. The value during the first sixty-second-period after acetylcholine was estimated to be $0.57 \mu \mathrm{g}$. per $\mathrm{kg}$. per minute, a little smaller than that after the first acetylcholine injection.

In Dog 5, the adrenaline content of the adrenal venous blood sampled before acetylcholine injection was too small to be quantified. After acetylcholine the rate of secretion was determined to be $0.53 \mu \mathrm{g}$. with the specimen, the collection of which was begun at the same time with the start of injection and lasted sixty seconds. With two successive specimens the rate of adrenaline secretion was estimated to be $0.02 \mu \mathrm{g}$. and $0.01 \mu \mathrm{g}$. per $\mathrm{kg}$. per minute, respectively. From these, the rate of adrenaline secretion during the first three-minute-period after acetylcholine was calculated as $0.19 \mu \mathrm{g}$. per $\mathrm{kg}$. per minute. The injection of acetylcholine was made after procaine. The adrenaline secretion rate daring the first three-minute-period after the start of injection amounted to $0.01 \mu \mathrm{g}$. per kg. per minute.

In Dog 6, the adrenaline secretion before the first acetylcholine injection was unmeasurably small. After acetylcholine it increased exceedingly. With the specimen taken in the first sixty-second-period it was estimated to be 1.3 $\mu \mathrm{g}$. per minute. The rate of adrenaline secretion during the second sixty-secondperiod was $0.05 \mu \mathrm{g}$. per $\mathrm{kg}$. per minute. Thus the mean value of adrenaline secretion rate during the first two-minute-period was $0.68 \mu \mathrm{g}$. per $\mathrm{kg}$. per minute. Twenty-five minutes later, procaine was injected and followed by another injection of acetylcholine. The adrenaline secretion rate before the second acetylcholine injection was $0.004 \mu \mathrm{g}$. After injection, its mean value during the first two-minute-period was estimated to be $0.18 \mu \mathrm{g}$.

\section{Tetraethylammonium}

As to the blood pressure in this series of experiments, almost the same features as those in the procaine experiments were obtained.

The basal rate of adrenaline secretion in Dog 7 was $0.02 \mu \mathrm{g}$. per kg. per minute. On receiving acetylcholine it increased to $0.32 \mu \mathrm{g}$. per $\mathrm{kg}$. per minute, which was estimated with the specimen collected during the first two-minuteperiod. Thirty minutes later, TEA was injected. Acetylcholine was then injected. Before acetylcholine injection, the rate of adrenaline secretion was 0.004 $\mu \mathrm{g}$. per kg. per minute. After the injection, the adrenaline content of the specimen taken during the first two-minute-period was too small to be estimated though the blood flow through the suprarenal gland was almost unaltered.

The initial rate of adrenaline secretion in Dog 8 was $0.009 \mu \mathrm{g}$. per $\mathrm{kg}$. per minute. With the specimen taken during the first sixty-second-period after the first acetylcholine injection it was $0.29 \mu \mathrm{g}$. per $\mathrm{kg}$. per minute. With the next specimen it was found to be under the pre-injection rate. Thus the mean value during the first two-minute-period was $0.15 \mu \mathrm{g}$. per $\mathrm{kg}$. per minute. Thirty minutes later, TEA was injected, and followed by the second injection of acetylcholine. With the specimen collected during the first two-minute-period, the adrenaline secretion rate was estimated to be $0.02 \mu \mathrm{g}$. per $\mathrm{kg}$. per minute.

The basal rate of adrenaline secretion in Dog 9 was estimated as $0.007 \mu \mathrm{g}$. 
per kg. per minute. After receiving acetylcholine it was $0.09 \mu \mathrm{g}$. in the sample collected during the first two-minute-period. In the specimen taken during the next two-minute-period it returned to a pre-injection value. Thirty-five minutes later, TEA was injected and followed by an injection of acetylcholine. The adrenaline secretion rate during the first two-minute-period was unmeasurably small.

In Dog 10 the initial adrenaline secretion rate was $0.06 \mu \mathrm{g}$. per kg. per minute. With the specimen sampled during the first thirty-second-period after injection of acetylcholine it was estimated to be $2.5 \mu \mathrm{g}$. per $\mathrm{kg}$. per minute. It was $0.17 \mu \mathrm{g}$. per $\mathrm{kg}$. per minute for the next thirty-second-period. The mean value of secretion rate during the first sixty-second-period after acetylcholine was thus $1.3 \mu \mathrm{g}$. per $\mathrm{kg}$. per minute. Thirty minutes later, TEA was injected. Then the second injection of acetylcholine was performed. The adrenaline secretion rate during the first sixty-second-period after this injection was $0.07 \mu \mathrm{g}$. per kg. per minute and that during the next sixty-second-period was unmeasurably small.

\section{DISCUSSION}

The experimental results described above indicate that procaine or tetraethylammonium prevents the augmentation of adrenaline secretion of the adrenal gland causable by acetylcholine. However, evidence against the results of the present investigation was given by Bergmann (10). In atropinized dogs under chloralose anesthesia he examined the effect of procaine on the blood pressure elevation elecitable by electrical stimulation of the splanchnic nerves or acetylcholine injection. Procaine was given in a dose of $50 \mathrm{mg}$. per kg. of body weight. Whereas the pressor effect of splanchnic stimulation was markedly reduced by procaine, the hypertension by acetylcholine was almost unaffected. From these he inferred that procaine had the effect of paralyzing the intrasuprarenal nerve endings of the adrenalino-secretory fibres and thus inhibiting the liberation of acetylcholine. The results of the present investigation do not coincide with those of Bergmann, as in most experiments a profound fall of the blood pressure instead of an elevation was caused by acetylcholine after application of procaine.

With tetraethylammonium Freyerburger, Capo and Moe (11) could not observe any suppressing effect on the blood pressure elevation in dogs causable by anoxia or asphyxia. They concluded that anoxia and asphyxia stimulate directly the adrenal medullary cells and that this effect cannot be prevented by tetraethylammonium. However, Sato, Inaba and Takahashi (12) failed to prove any acceleration of adrenaline secretion by asphyxiation in splanchnicotomized dogs and denied its direct action on the adrenal medullary cells. At present we are uncertain as to the reason for all the contradictory findings above mentioned.

\section{SUMMARY}

In dogs anesthetized with evipan-sodium, adrenal venous blood specimens were collected through the lumbar route without opening the abdominal cavity. Adrenaline content of the specimens was estimated colorimetrically using 
the arseno-molybdic acid method of Bloor and Bullen.

After administration of atropine, acetylcholine in a dose of 2-3 mg. per $\mathrm{kg}$. was injected. On receiving acetylcholine the adrenaline secretion rate was estimated to be markedly augmented. After a while, procaine in a dose of 50$70 \mathrm{mg}$. per $\mathrm{kg}$. or tetraethylammonium in a dose of $10-20 \mathrm{mg}$. per $\mathrm{kg}$. was injected. After procaine or tetraethylammonium, acetylcholine in the same dose as before used to cause little or no increase in the rate of adrenaline secretion.

My thanks are due to Prof. T. Suzuki for his helpful advice in this work. The technical assistance of Drs. I. Tanaka and C. Ninagawa throughout these experiments is greatly appreciated.

\section{REFERENCES}

1. HAZARD, R. AND CoRteggiani, E. C. R. Soc. Biol. $137:$ 157, 1943.

2. BERGMANN, F. C. R. Soc. Biol. 142 : 1187, 1948.

3. MORRISON, J. L. Fed. Proc. 6: 359, 1947.

4. Morrison, J. L. ANd Farrar, C. H. Proc. Soc. Exp. Biol. Med. 71: 235, 1949.

5. Morrison, J. L., Heymans, C., Richardson, A. P. AND Walker, H. A. Arch. intern. Pharmacodyn. 86: 203, 1951.

6. Malméjac, J., Chardon, G. ANd Neverre, G. C. R. Soc. Biol. $145:$ 701, 1951.

7. Jourdan, F. AND DUChÊNE-MARUllaz, P. C. R. Soc. Biol. 145: 1315, 1951.

8. Satake, Y., SugaWARA, T. AND WatanABe, M. Tohoku J. Exp. Med. 8: 501, 1927.

9. BloOR, W. R. AND Bullen, S. S. J. biol. Chem. 138: 727, 1941.

10. BERGMANN, F. Etude du mode d'action de la procaine en administration intraveineuse. Bruxelles, 1950.

11. Freyburger, W., CAPO, L. ANd MOE, G. K. Fed. Proc. $7: 220,1948$.

12. Sato, H., InABA, T. AND TAKahashI, W. Tohoku J. Exp. Med. 19: 421, 1932. 